\title{
DIE ROL VAN KLEURLINGE IN SUID AFRIKA SE MILITÊRE VERLEDE
}

KO A.M. Le Roux*

This essay gives a general description of the valuable and willing participation by many members of the Coloured community in the defence of South Africa throughout its military history. Today Coloured volunteers and aspirant permanent force members serve in the Cape Corps after having passed a stringent selection process. Today Coloureds also serve in the air force, navy, medical services and the commandos and many also do their bit with other South Africans in the operational area.

\section{Inleiding}

Die inwerkingtreding van die nuwe Grondwet van die Republiek van Suid-Afrika bring mee dat die Kleurlinggemeenskap nou op die hoogste vlak saam met Blankes en Indiërs inspraak in Verdedigingsake het. Die Suid-Afrikaanse Kaapse Korps het insgelyks sy 21 ste bestaansjaar in April 1984 gevier terwyl die SuidAfrikaanse Kaapse Korps Oudgediendes Legioen in die jaar sy 40ste verjaardag herdenk het. Op die oog af wil dit voorkom asof die Kleurlinggemeenskap se aandeel in Suid-Afrika se historiese verlede kwalik verder as vier dekades strek en as sodanig betreklik resent is. Dit is allesbehalwe die geval, want hierdie volksgroep het ' $n$ lang en kleurryke historiese verbintenis met die miltêre verlede van Suid-Afrika. Die feit dat die Kleurlinge nou op die drumpel staan van 'n nuwe tydvak in die staatkundige ontwikke-

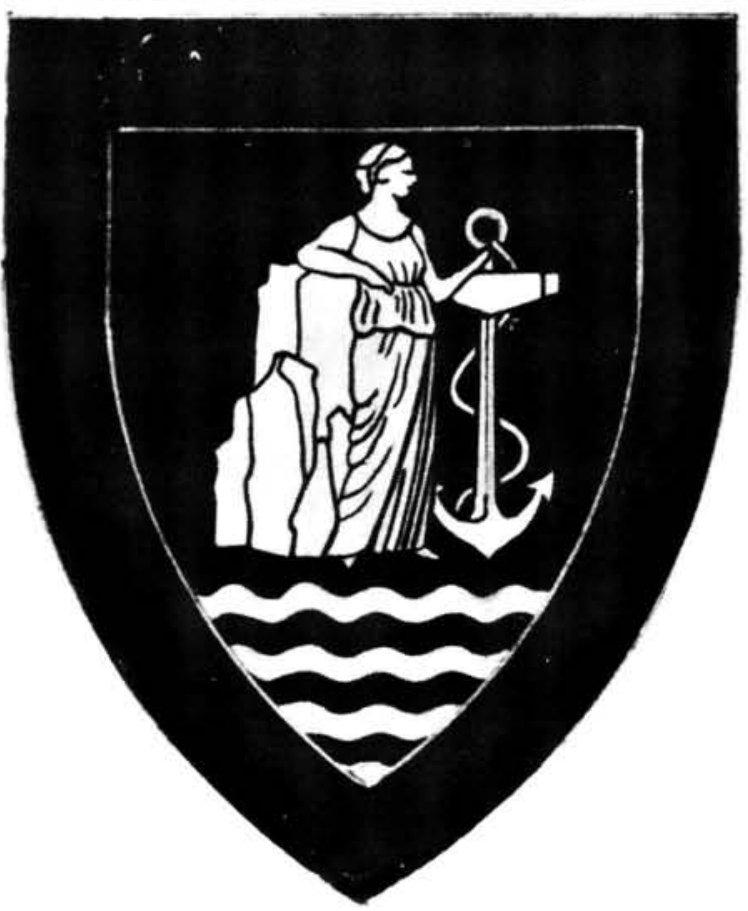

ling van die Republiek van Suid-Afrika, beteken ook nie dat hulle vir die eerste maal ten nouste met verdedigingsake gemoeid sal wees nie.

Die Kleurlinggemeenskap se historiese verbintenis met Suid-Afrika se krygsverlede is in sigself 'n besondere Geskiedenis met vele hoogtepunte. In hierdie oorsig word hierdie kroniek slegs in breë trekke beskryf. Ofskoon dit nie in 'n historiese sin volledig is nie, kan dit minstens ' $n$ insae verskaf in ' $n$ onderwerp wat in die huidige tydsgewrig net so aktueel as 300 jaar gelede is.

Uit die vroegste tydperk van die Kaapkolonie blyk dit dat verdediging die taak van Blankes sowel as Nie-blankes was. Die verdediging was beide teen buitelandse moondhede en plaaslike vyande gemik. In 1661 byvoorbeeld het die Verenigde Oos-Indiese Kompanie (VOC) 'n ekspe-

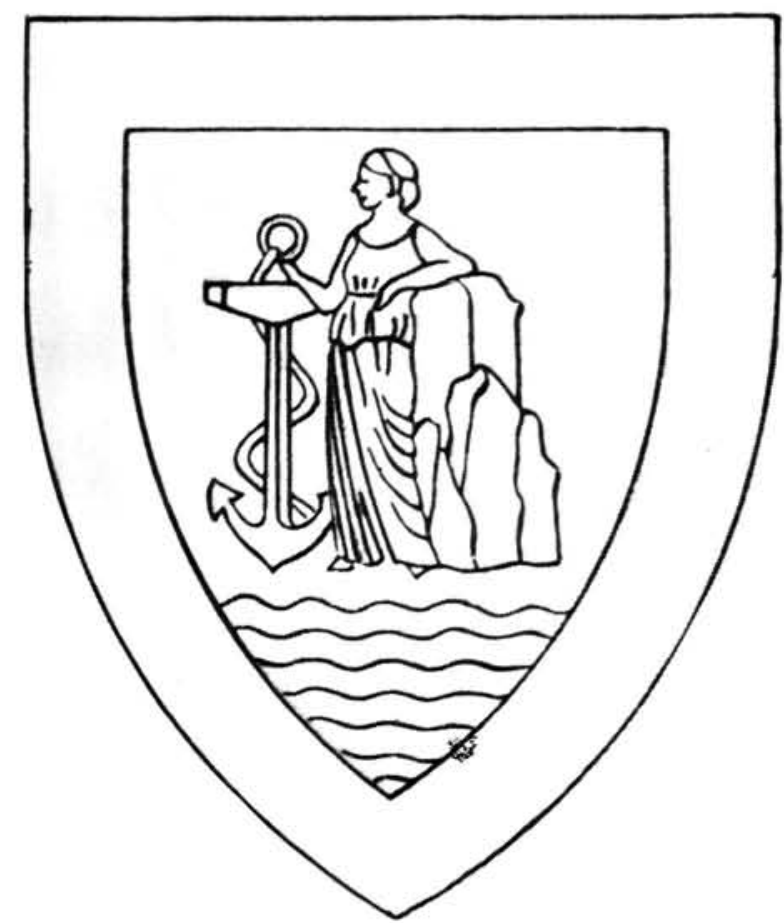

SAKK Kenteken 
disie teen die Hottentotte geloods terwyl Kaapmans die Blankes bygestaan het. In 1674 het 'n regeringskommando, waaronder daar Hottentotte was, teen die Boesmans opgetree en in 1676 het 'n blanke kommando met Hottentotte teen die Sonkwas te velde getrek. Die destydse VOC-beleid kom duidelk na vore in 1700 toe blanke koloniste en Hottentotte as dienspligtig beskou is. ' $n$ Uitvloeisel van hierdie beleid is in 1741 gevind toe daar bepaal is dat Blankes die Nie-blankes wat kon skiet, moes saamneem wanneer hulle opgekommandeer word. In 1781 is die Regiment Pandoere wat uit vrygestelde slawe bestaan het, deur die VOC as deel van die Staande Mag opgerig. In 1787 is 'n Kleurlingkorps, "Corps der Vrijen", wat deur blanke offisiere aangevoer is, in die lewe geroep. Die rol wat die Kleurlinge in verdedigingsaangeleenthede gespeel het, is in 1795 versterk toe die taak van militêre versterking soos loopgrawe heeltemal aan die Pandoere oorgedra is.

Tydens die Britse Bewind (1795-1803) het hierdie beleid van verdediging nie verander nie. Verdedigingstake is deur Blankes en Nieblankes verrig en die oorlog teen Hdlambi is hier van belang, toe blankes en Hottentotte saam geveg het. Die nie-blanke verdedigers van die VOC wat in 1795 teen die Britse besetting gebruik is, is in 1797 deur It J. Cambell saamgesnoer as die Cape Corps toe hulle onder die leiding van 98th Foot Regiment gekom het. Hottentotte is ook in 1801 gebruik om die Van Jaarsveld-rebellie te help onderdruk. Hierdie keer is Kleurlinge as wadrywers, touleiers en veewagters aangewend. Die korps het in 1802 as die Hottentot Light Infantery bekend gestaan met ' $n$ sterkte van tussen 500 en 600 man.

Gedurende die Bataafse Bewind (1803-1806) het 'n ligte infanterie Hottentotte regiment onder die bevel van blanke offisiere bly voortbestaan. Hierdie eenheid het dan ook in 1806 gehelp met die verdediging van die Kaapkolonie. Met die tweede Britse Besetting, is die Engelse benaming van Cape Corps verander na Cape Regiment. In verband hiermee het maj Tylden die volgende gesê:

(a) "As the name implies, other ranks have always been Eurafricans bred in the Cape Colony, although any coloured man could usually enlist."

(b) "The name Cape Corps, persisted unofficially for many years, applied to the C.M.R. (Cape Mounted Rifleman, Imperial).
Bogenoemde eenheid is aanvanklik onder die benaming Cape Regiment onder maj John Graham in 1806 as 'n infanterie-regiment met 'n sterkte van tien kompanies gestig. Op 17 September 1817 is die eenheid feitelik in sy geheel ontbind toe slegs ' $n$ klein getal infanteriste onder die benaming Cape Light Infantery voortbestaan het. ' $n$ Berede afdeling, bekend as die Cape Cavalry, is vir die verdediging van die Oosgrens in die lewe geroep.

Die Kleurlingeenheid is op 27 November 1827 saamgesnoer onder die naam Cape Mounted Riflemen en het onder hierdie naam berede eenheid diens verrig tot 1870 . In 1850 is die samestelling van die Korps verander na twee-derdes Blank en een-derde Nie-blank. Geen Nieblankes is verder aangestel nie. Die sterkte van die Korps deur hierdie periode het gewissel van tussen 300 en 1000 lede. In die periode tot 1870 het Kleurlinge as lede van die C.M.R., in 1842 aan die Britse militêre besetting van Port Natal deelgeneem. So het hulle ook in 1948 aan die Slag van Boomplaats deelgeneem asook aan verskeie Kaapse grensoorloë.

\section{Eerste Wêreldoorlog}

Van 1870 tot 1915 het Kleurlinge nie weer in vegtende hoedanigheid aan militêre optredes deelgeneem nie. Hulle het wel tydens die Anglo Boere-oorlog as kokke en wadrywers deelgeneem. Met die uitbreek van die Eerste Wêreldoorlog in 1914 is die Kleurlinge in nie-vegtende hoedanigheid in die veldtog in Duits-Suidwes Afrika aangewend. In teenstelling met die Nieblankes in Duitse militêre diens is hulle nie bewapen nie. Die Kleurlinge het in hierdie veldtog belangrike werk by krygsbehoefte-, kommissariaat-, transport- en remontedepots en in militêre hospitale verrig. Sowat $35000 \mathrm{Nie}$-blankes is in hierdie take aangewend. Dit is egter onmoontlik om te sê hoeveel Blankes en Kleurlinge afsonderlik betrokke was. Na hierdie veldtog is ' $n$ werwingsveldtog van stapel gestuur om Bantoes en Kleurlinge op ' $n$ vrywilligergrondslag en in nievegtende poste saam met die Imperiale magte na Duits-Oos-Afrika, Frankryk en Palestina te stuur. Die Kleurlinge het egter vertoë gerig om saam in 'n eenheid gegroepeer te word. Die gevolg hiervan was die totstandkoming van 'n Kleurling-infanteriebataljon op 20 September 1915. Slegs die offisiere van die bataljon was blankes en die eerste bevelvoerder was it kol G.A. Morris van die Natal Carbineers. Sy aanstelling was van 5 Oktober 1915 van krag. Aanvanklik het die bataljon bekend gestaan as die 
Cape Corps Battalion, maar is later tot 1 st Battalion Cape Corps herdoop.

Simonstad is as mobilisasiesentrum aangewys. Die lede is op dieselfde diensvoorwaardes as die Imperialetroepe aangestel wat beteken het dat hulle in diens moes bly tot ses maande na die oorlog. Soldy is op dieselfde skaal as die van Britse infanteriste betaal. Die blanke lede van die bataljon is egter volgens die Unieverdedigingsmag se tariewe besoldig.

Inswering van rekrute het op 25 Oktober 1915 'n aanvang geneem en die belangstelling was sodanig dat die bataljon op 12 Desember op volle sterkte was. Einde Januarie 1916 was die basiese opleiding van die bataljon afgehandel en op 9 Februarie het die Cape Corps aan boord van die Armadale Castle na Mombasa vertrek vir deelname aan die Duits-Oos-Afrika-veldtog. Daarvandaan is hulle per spoor na Kajido vanwaar hulle na die front by Langado-West gestuur is. Op die gevegsterrein is die bataljon tot die 2de Brigade van die 1ste Oos-Afrikaanse Divisie toegevoeg. Die eerste Oos-Afrikaanse Divisie het sy aanval op 5 Maart 1916 begin en die volgende dag is aan 129 Baluchis en 600 lede van die Cape Corps opdrag gegee om Ngare Nairobi vanuit die Nanjubimoerasse aan te val. Die nag van 7 en 8 Maart het die Cape Corps sy vuurdoop gehad. Met ondersteuning het hulle Ngare Nairobi op 8 Maart binnegeval. Tot in Junie 1916 was die Cape Corps verantwoordelik vir die verbetering en versterking van verbindingslyne. Met hierdie taak het hulle baie lof ingeoes. Na die voltooling van hierdie taak het die eenheid op Tsame saamgetrek waar dit by die divisietroepe as deel van die veldformasie ingedeel is.

In Julie 1916 het 'n gedeelte van die bataljon, onder bevel van maj Hoy, na Lubigura opgeruk om die vyand te probeer keer. Die bataljon was daarna verantwoordelik vir die Kangata-Houdinisektor. Dit het daarop neergekom dat $40 \mathrm{~km}$ padlengte streng bewaak moes word. In die uitvoering van bogenoemde taak is die eerste medalje vir verdienste aan 'n Kleurling toegeken. Die terugvallende vyand het verskeie myne op die pad gelê en kpl Dernos het, hoewel hy niks van myne geweet het nie, ' $n$ Duitse myn onskadelik gestel.

Nadat die Kleurlinge ook betrokke was in die verowering van die Morogoro, het hulle van 2 September tot 12 Desember 1916 'n welverdiende ruskans gekry om te herstel van ver- moeienis en siektes soos malaria en dissentrie. Gedurende hierdie rusperiode is die Cape Corps oorgeplaas na die Tweede Brigade van die Derde Oos- Afrikaanse Divisie wat onder bevel van genl maj Coen Brits was. Hulle het versterkings ontvang van maj Hoy en kapt Tondy wat op 15 Oktober na Tanga vertek het asook 600 soldate wat reeds uit hospitale ontslaan as en weer opgelei sou word. Ook vanuit SuidAfrika het hulle rekrute vir die bataljon ontvang. Sodoende is die bataljon met twee kompanies vergroot en is die sterkte van 1500 man oorskry. Maj Hoy het op 15 Desember 1916 met 1350 korpslede by nog versterkings uit Suid-Afrika aangesluit. Dit het die totale sterkte van die Cape Corps in Oos-Afrika op 2000 te staan gebring.

Op 12 Desember 1916 het die opmars na die Rufiji-gebied begin. Lt kol Morris was in bevel van die A en D Kompanies, wat uit 770 man bestaan het. Maj Hoy het die B en C Kompanies met ' $n$ sterkte van 750 man aangevoer. Mediese gevalle en oortollige bagasie is onder beheer van kapt Jardine agtergelaat. Op 2 Januarie 1917 het 500 lede van die Cape Corps, 'n seksie van 1 Kashmir Mountain Battery en die Faridkot Pioneers (Indië) 'n opmars van twaalf ure begin. Hulle het ' $n$ kamp aan die oorkant van die Rufijirivier met 'n bajonetstormloop uitgewis. Agtien dae later het die volgende skermutseling, waarby Kleurlinge betrokke was gevolg. Sowat 685 korpslede van It kol Morris het 800 vyandelike troepe na 'n geveg die aftog laat blaas.

Malaria en dissentrie het onder die troepe van die Cape Corps uitgebreek, waar hulle tydens die reënseisoen op Mpangas saamgetrek was. Op 17 Februarie het maj Hoy met 'n kolonne siektes na Morogoro vertrek terwyl It kol Morris die oorblywendes in verdere offensiewe aangevoer het. Hierdie groep het egter op 12 Maart ook in Morogoro aangekom en van die 1500 gesonde troepe van dertien weke tevore het slegs die bevelvoerder, vyf offisiere en vyf-ensestig uitgeteerde manskappe oorgebly. Malaria, dissentrie, honger en swaarkry het sy spore gelaat.

Die eenheid het nie kans gekry om uit te rus nie, want op 17 April het maj Hoy opdrag gekry om met die lede wat reeds herstel het na Itigi te vertrek. Van die 28 offisiere en 800 manskappe was slegs 14 offisiere en 400 manskappe in die kamp in staat om te vertrek. Hulle het van Itigi af ses dae lank deur moerasse gesukkel om by Kiromo uit te kom waar kol Murray bevel oorge- 
neem het. ' $n$ Maand later is die afdeling na Malongwe waar hulle 'n paar weke garnisoendiens verrig het. Op 10 Julie vertrek It kol Morris met 19 offisiere, 526 lede van die Cape Corps, 109 masjiengeweer- en een-en-twintig draagbaardraers per trein van Morogoro na Arusha. Maj Hoy en sy kolonne het op 20 Julie na Dodoma vertrek.

Op 1 Oktober slaag It kol Morris om die vyandelike aanvoerder Naumann tot oorgawe te dwing. Hulle kon nou na Morogoro terugkeer. Die hele bataljon is per skip op 30 Oktober na Njangao teruggeneem. Met ' $n$ versterking van 226 draers ruk It kol Morris op 5 November teen die vyand te Mkungu op. Die geveg het ' $n$ paar dae geduur en in hierdie tyd het vier korpslede toekennings vir dapperheid op die slagveld verwerf. Die lede was It Samuelson, kpl Abrahams, o/kpl Le Roux en kwartiermeester-sersant-majoor Calvert. Die sitaat $\mathrm{mbt} \mathrm{o} / \mathrm{kpl}$ Abrahams, soos ontleen aan die byvoegsel tot die London Gazette van 18 Februarie 1918 (2172) lui soos volg:

"For conspicious gallantry and devotion to duty. During the attack on a difficult and important objective he displayed great courage and initiative, and in the consolidation of the same showed marked qualities of skill and leadership, rendering valuable assistance"

Betreffende KSM C. Calvert, DCM, getuig die sitaat wat gepubliseer is in die byvoegsel tot die London Gazette van 28 Maart 1918 (2893) soos volg:

"For conspicious gallantry and devotion to duty. When his company commandor and two other officers became casualties, he rendered valuable service in helping to organise the firing line, and in bringing up the ammunition under concentrated gun fire. His fearlessness and bold initiative were only equalled by his energetic efforts under conditions and great danger and difficulty .

Op 11 November het die bataljon Nangoo beset en daarna na Massai vertrek. ' $n$ Deeglike mediese ondersoek van die bataljonlede het daarop gedui dat hulle ongeskik vir aktiewe diens was. Op 20 December 1917 is die Cape Corps aan boord van die Caronia in Dar-es-Salaam en op Kersdag in Durban aangekom. Van Durban af is die bataljon na Kimberley waar hulle te Riverton gehuisves is.
Die eerste bataljon van die Cape Corps, se goeie werk in Oos-Afrika het die gedagte laat ontstaan om 'n tweede bataljon op die been te bring. Op 15 Maart 1917 is die nodige magtiging daartoe verleen en die aanvanklike sterkte was twee kompanies terwyl nog twee later bygevoeg is. Blanke offisiere en onderoffisiere is uit OosAfrika onttrek om die opleiding waar te neem. Lt kol J.C.B. Clayton is op 5 Junie 1917 as bevelvoerder aangewys terwyl maj R.W. McCluskie op 1 julie as tweede-in-bevel van die tweede bataljon aangestel is. Die bataljon is in drie groepe per trein na Niassaland vervoer waar hulle gedurende Julie en Augustus aangekom het vir verdere opleiding te Blantyre.

$\mathrm{Na}$ hulle opleiding is 2 Bataljon Cape Corps te M'tengula te Portugees-Oos Afrika in die veld gestoot om patrolliewerk te verrig. Op $22 \mathrm{Mei}$ het hulle aan hulle eerste geveg by Chisan deelgeneem en die vyand swaar verliese toegedien. Met die afname van krygsverrigtinge in DuitsOos-Afrika het 2 Bataljon Cape Corps teruggetrek met die uitsondering van nege offisiere, tien onderoffisiere en 486 man wat na Egipte gestuur is as versterking van 1 Bataljon. Die oorblywende lede van 2 Bataljon het in September 1918 in Kimberley aangekom waar hulle in November en Desember ontbind is.

Op 3 April 1918 is 1 Bataljon Cape Corps na 'n rusperiode weer gemobiliseer en aan boord van die Magdalena van Durban na Egipte gestuur. Die eenheid het op 20 April 1918 te Kantara aangekom waar hulle aanvanklik vir garnisoendiens aangewend is, maar later opleiding ontvang het om in Palistina te gaan veg. $\mathrm{Na}$ die opleiding het die eenheid op 15 Julie na die Palestynsefront, met Rham Alla as bestemming vertrek. Die Bataljon is egter met malaria, dissentrie en griep getref. Die gevolg hiervan was dat daar slegs 340 manne slaggereed was op 20 Augustus. Die syfer het op 18 September na 261 man opgeskuif.

Die groot offensief het egter op 17 September begin. Gedurende die nag van 18 en 19 September het die Cape Corps as voorhoede Wye Hill en Square Hill aangeval en 181 Turke gevange geneem. Die geveg het die hele volgende dag geduur, totdat die offisiere van A en B Kompaniese sodanig verwond was dat hulle nie kon aangaan nie. Onderoffisiere het die leiding oorgeneem en die gevegsterrein Square Hill ontruim. Ses offisiere het in die geveg gesneuwel een en het later aan sy wonde beswyk. Veertig 
van die manskappe is gedood, 103 gewond en ses manne het later aan hulle wonde beswyk.

Hierdie geveg het ' $n$ aantal DCM-toekennings opgelewer - o/kpl I.W. Arendse, kwartiermeester-sersant-majoor D.J. Brown, sers J. Swartz, sers M. Frebruary, o/kpl W.H. Hutchinson en sers S.D. Jansen. Die sitaat van o/kpl Arendse word hieronder aangehaal.

"For conspicious gallantry and devotion to duty. This NCO, when his officer and machine gun crew had been either killed or wounded, and the gun out of action and left dangerously near the enemy exposed to heavy machine gun fire, made gallant attempts to recover it, ultimately succeeding in doing so, and there after efficiently handling it against the enemy. Every time this NCO has been in action he has been highly spoken of".

$\mathrm{Na} 21$ September is die bataljon vir herwinningswerk aangewend aangesien daar nie weer verdere gevegte was nie, Nadat die oorlog op 31 Oktober 1918 in die Midde-Ooste beeïndig is, is die korps terug na Egipte. Tydens onluste in Maart 1919 is die lede vir garnisoendiens in Alexandrië gebruik. Op 6 Augustus het hulle aan boord die Tambo na Kaapstad vertrek waar hulle op 5 November gedemobiliseer en die eenheid ontbind is.

Die twee bataljons Cape Corps het in die Eerste Wêreldoorlog sowat 7000 man in die veld gehad. Lede het die vlgende dekorasies verwerf.

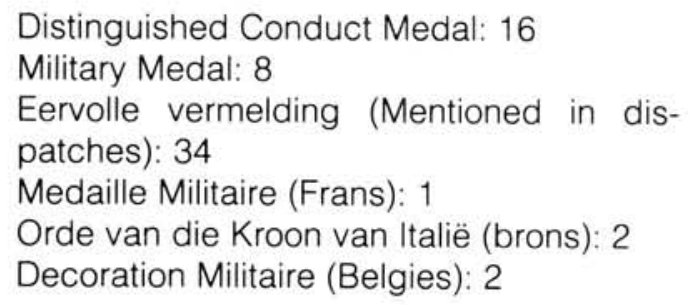

Die twee bataljons het ook die volgende Britse gevegsonderskeidings ontvang:

1 Bataljon: $\begin{aligned} \text { Negiddo } \\ \text { Nablus } \\ \text { Palestine 1918 } \\ \text { Kilimanjaro } \\ \text { Behobeho } \\ \text { Nyango } \\ \text { Oos-Afrika 1916-17 }\end{aligned}$

2 Bataljon: Oos-Afrika 1917-18
Bo en behalwe die twee Infanteriebataljons wat die oorlog in ' $n$ vegtende hoedanigheid meegemaak het, was daar ook twee nie-vegtende eenhede wat sodanige oorlogsdiens verrig het en vermelding verdien. Hulle was die 1 Cape Coloured Labour Battalion en die Cape Auxiliary Horse Transport. Eersgenoemde eenheid is op 8 Junie 1916 gemagtig en het uit Kleurling-dokwerkers bestaan. Die mobilisasiedepot was te Rosebank (Kaapstad) en het later na Simonstad verskuirf. Op 1 September 1916 het 1020 manskappe, gevolg deur 424 manne op 21 September 1917 en 500 mans op 12 Mei 1918 in Frankryk aangekom. Hulle het uitstekende werk in Frankryk verrig en het eers in Julie 1919 na SuidAfrika teruggekeer.

Teen die einde van 1916 was die mannekragposisie in Europa haglik. Die Britse Regering het die Unieregerng versoek om agt kompanies, bestaande uit 2316 Kleurlingdrywers, vir diens in Frankryk verwerf. Op 17 Maart 1917 het die Unieregering ' $n$ eenheid by De Beersmyne te Kimberley gemobiliseer, wat bestaan het uit 3482 gewerfde troepe. Lt kol J.D. Anderson is reeds op 25 Februarie 1917 as bevelvoerder van die groep aangewys.

Die eerste groep het op 2 Julie 1919 met die Ebani na Suid-Afrika teruggekeer terwyl die laaste groep op 22 Augustus 1919 aan boord van die Chepston Castle gerepatrieer is. Kort daarna het hulle ontbind.

\section{Tweede Wêreldoorlog}

Na die uitbreek van die Tweede Wêreldoorlog is Kleurlinge weer aangewend om in die aanvraag na arbeid in die Unieverdedigingsmag te voorsien. Die vertroue wat in die Kleurlinggemeenskap gestel is, blyk uit die aanhaling uit ' $n$ verklaring van kol E.T. Stubbs, DNEAS (Director Non European Services):

"When the Union Government asked my opinion as to the possibility of obtaining man-power of the Coloured, to further the war effort, I knew the response would be great.

I consulted the leaders of the Coloured, who are all personally known to me, and whose confidence I have, with the result that with their co-operation recruits of all callings, and representing the cream of the Coloured Communities throughout South 
Africa, from all corners, flocked to the colours ...".

Lt kol N.C. Hoy, DSO, het op 8 Mei 1940 opdrag gekry om onmiddellik met die rekrutering en vorming van vyf transportkompanies te begin. Kimberley sou die basis wees en werwingskantore is te Pretoria, Port Elizabeth, Kimberley en Johannesburg geopen.

Een van die eerste probleme was die verkryging van geskikte instrukteurs. Twaalf peletonsersante van 1 Bataljon Cape Corps van die Eerste Wêreldoorlog is gewerf. Hulle is in Kimberley aan 'n opfrissingskursus asook ' $n$ aanvullende opleidingskursus onderwerp. $\mathrm{Na}$ afloop van die kursus is al die sersante bevorder tot stafsersant-instrukteur. Al die aanvanklike kompanies het hulle basiese opleiding onder hierdie instrukteurs ontvang. Die akkommodasieprobleem is opgelos nadat De Beers Consolidated Diamond Mines Ltd, Kimberley na onderhandelinge die mynkamp Bultfontein op 26 Mei 1940 vir die Kleurlingkorps verkry het.

Die eerste rekrute is eers aan die begin van Julie ontvang aangesien daar ' $n$ tekort aan komberse en jasse was. Vanweë die gunstige reaksie van die Kleurlinggemeenskap was dit nodig om die kampe Du Toitspan en Wesselton ook van die De Beersmaatskappy te huur.

By Bultfontein is ' $n$ motortransportdepot met ' $n$ bestuurderskool ingerig. Kort daarna het ' $n$ toegeruste werkswinkel wat alle herstelwerk kon behartig en werktuigkundiges kon oplei gevolg. Vyftien motortransportkompanies is daar tot stand gebring terwyl alle ander eenhede tot op volle sterkte gebring is deur voertuigbestuurders wat uitgeplaas is. Sewentien Pionierskompanies het hulle ontstaan te danke aan die Werkdepot wat te Du Toitspan gevorm is. By Wesselton is ' $n$ ontvangsdepot ingerig en rekrute het daar hulle basiese opleiding ontvang. Hulle is ook van daar af uitgeplaas na afdelings waar hulle opleiding ontvang het. Basiese opleiding was selde langer as die volle ses weke, omdat die aanvraag so groot was dat rekrute vroeër uitgeplaas is.

Tegniese opleiding is aanvanklik beperk tot voertuigbestuur en voertuigherstel asook die maak van paaie. Spesialisopleiding is later verskaf namate behoeftes in terme van mannekrag opgeduik het. Op 15 Julie 1940 het die Adjudant-generaal beslis dat die korpsindeling soos volg sal wees:

(a) Kleurlingkorpshoofkwartier

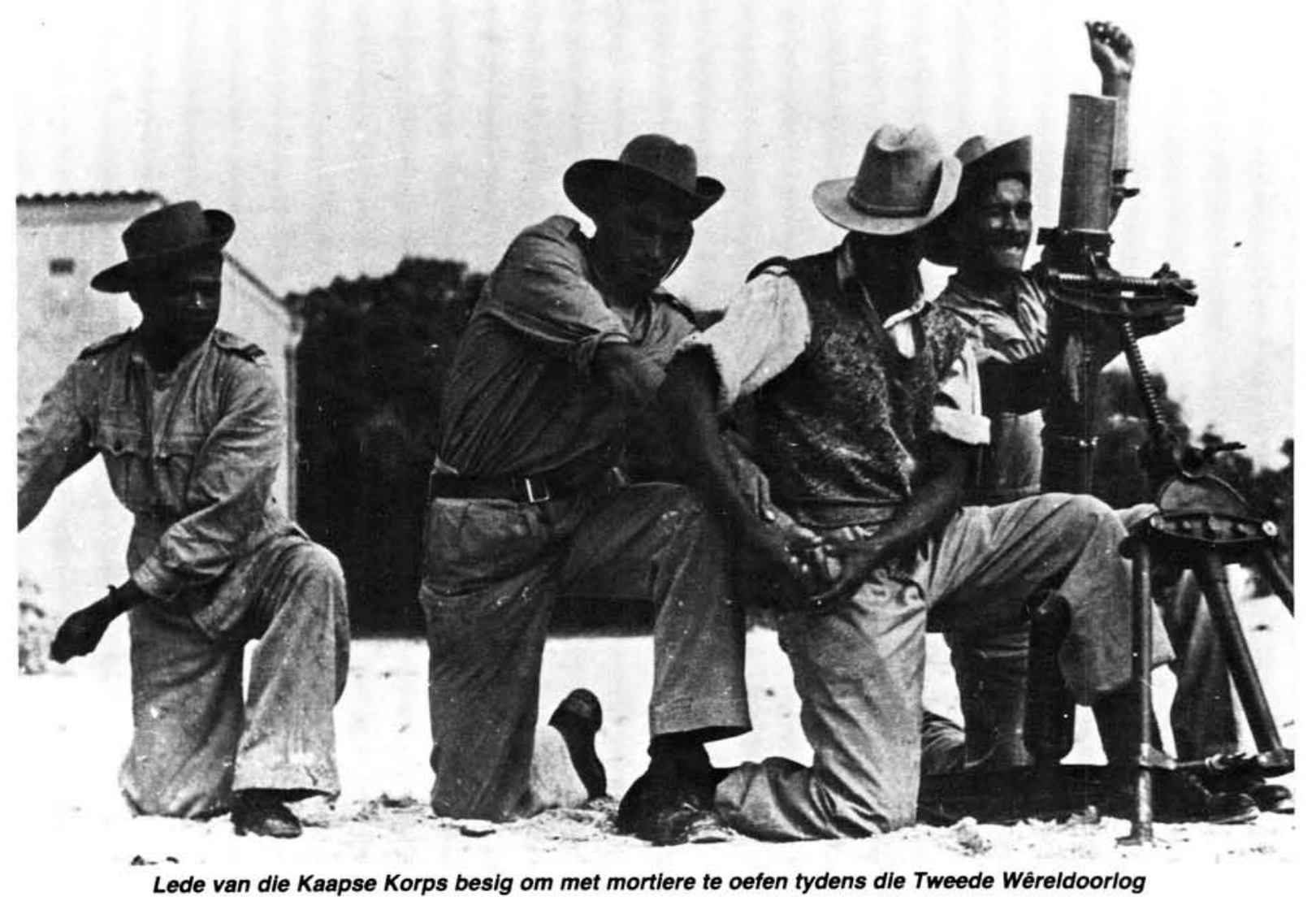


(b) Pionierskompanies

(c) Motortransportkompanies

Opdrag is gegee dat $30 \%$ van die reserviste opgelei sal word om 'n depotkompanie te vorm. Instrukteurs en administratiewe personeel sou uit die Kleurlingkorpshoofkwartier getrek word. Op 21 September 1940 is bepaal dat die motortransportkompanie soos volg sal heet: A-E MT Companies Cape Corps. Die kompanies het so gegroei dat die alfabet tot by "N" gebruik is.

A en B kompanies het op onderskeidelik op 3 en 9 September reeds oor Broken Hill na Kenia vertrek. D Kompanie het Suid-Afrika op 24 September verlaat en is deur E Kompanie op 28 September, H Kompanie op 16 Oktober en $J$ Kompanie op 15 November gevolg.

Die geweldige taak wat die drywers uitgevoer het word in die volgende aanhaling uit die Cape Corps Souvenirs onderskryf:

"Until you have travelled on some of these roads and have experienced the trying conditions under which these men have to work you can never appreciate what they are going through, yet you never hear a grouse - on the contrary the men are never anything but cheerful and of good spirit and only too ready to do whatever is required of them"

Hierdie kompanie se taak was om voorrade vanaf Nairobi na die voorste linies - onder onbegaanbare omstandighede - te vervoer. Dikwels het hulle by ' $n$ punt uitgekom met die nodige voorrade, net om te vind dat die troepe reeds vooruitbeweeg het na 'n punt wat nie op die kaart aangedui was nie. Die vragmotors wat deur Kleurlinge bestuur is het spoedig bekend geword as die "Cape Lorries".

Generaal J.C. Smuts het in 1941 in 'n Volksraadsdebat die volgende aanmerking gemaak:

"In Eritrea they won a great name. I have been told by the Commanding Officer that, were it not for the work of out Coloured drivers, the amazing campaigns which took our troops to Keren in a few weeks would not have been possible"

Die verskillende motortransportkompanies is by Nairobi verdeel. Een groep is na die Rudolph- meer gestuur ter ondersteuning van die gevegsmagte. Ander is weer gebruik vir gevegsliniewerk tussen Nairobi, Nanyuki en Wajir terwyl ' $n$ derde groep in die rigting van Mogadiscio beweeg het. Vandaar het hulle na Abeba oor Jijiga en Diredawa opgeruk.

Die aantal Kleurlingkompanies in Oos-Afrika het teen Maart 1941 toegeneem tot 23. Die eerste vier kompanies nl A, B, C en E het intussen oor land met die Nylroete tot in Eritrea gevorder. Daar het hulle ondersteuning aan Britse en Indiese gevegstroepe gebied. Die oorblywende Kleurlingkorpsmotortransporteenhede het, namate die gevegsfront in Oos-Afrika verskuif het, in die rigting van Abesinië en later Eritrea beweeg. By die beslissende slag in Keren was almal teenwoordig. Ongeveer 5500 lede van die Kleurlingkorps was by die Oos-Afrika-veldtog as lede van motortranspotkompanies betrokke, terwyl 1500 lede by konstruksiekompanies diens gedoen het.

Teen die einde van 1941 het die behoefte van die Unieverdedigingsmag drasties verander na die oorwinning oor die Italiaanse magte in Abessinië en Eritrea. Die gevegsfront het na die noordelike woestyngebied verskuif waar die uitgedunde Italiaanse strydmagte deur swaar Duitse versterkings aangevul is. $\mathrm{Na}$ die verwoestende veldslag by Sidi Rezegh is die vyfde Suid-Afrikaanse Brigade aanmerklik uitgedun en het die eerste Suid-Afrikaanse Divisie dringende versterkings genoodsaak.

Die aanvraag na versterkings het veroorsaak dat talle Kleurlingkorps-motortransportkompanies en werke-eenhede ontbind het en is die lede in groot getalle tot gemelde Divisie, veral as voertuigbestuurders, werktuigkundiges en kokke toegevoeg. Slegs A, B, D, E en N Kompanies het teen Junie 1942 oorgebly van die totale reeks motortransportkompanies wat deur Oos-Afrika gekom het.

N Kompanie is later herdoop na 133 South African Road Motor Transport Company, Cape Corps. Hulle is later die moeilike taak opgelê om voertuie na Turkye te vervoer. Vir ses maande lank het hierdie eenheid duisende voertuie na die Nyldelta deur die Sinaiwoestyn, Palestina en Sirië na Aleppo vervoer waar die voertuie aan die Turkse owerhede oorhandig is.

1 SA Divisie is onttrek aan die krygsverrigtinge na die veldslag van El Alamein en teen die einde van 1942 is hulle na Suid-Afrika teruggestuur. Dit 
het aan 2000 lede van die Kleurlingkorps die geleentheid gegee om na Suid-Afrika terug te keer. Aan die einde van 1943 is daar ' $n$ einde aan die veldtog op die vasteland van Afrika gemaak toe die Spilmagte finaal uit Tunisië verslaan is. Direk daarna het die inval in Europa gevolg.

Die enigste Kleurlingkonstruksiewerkers wat saamgeneem is Europa toe, is die wat verbonde was aan die Spoorweg Konstruksie Kompanies. Die aankoms van die sesde SA Paserdivisie in Europa was die oorsaak dat 21300 Kleurlingkorpslede wat as voorrade-klerke, voertuigbestuurders en draagbaardraers diens gedoen het. In 1944 het 104 Kleurlingkorpsbataljon in Algiërs aangekom en die pligte van sekerheidswagte uitgevoer. Twee maande later het die SA Geniekorps se vliegveldkonstruksiekorps met 250 Kleurlinge as lede van 157 en 158 Werkskompanies, asook 50 Kleurlinge in elk van 30 en 32 Padkonstruksiekompanies in Oran spgedaag. Daarna het hulle na Rabat vertrek ten einde een van die modernste vliegvelde in Afrika te bou.

Die getal geskoolde, halfgeskoolde en ongeskoolde Kleurlinge wat by die konstruksiewerk betrokke was, het nou tot 600 aangegroei. Teen die einde van 1944 was hierdie taak voltooi en die werksgroepe is na Tripoli-Wes en die MiddeOoste verplaas. Eenhede van die Kleurlingkorps wat na Mei 1943 gevorm is vir verskillende Werke- en Konstruksiekompanie, 136, 137, 138 en 139 Kleurlingkorps- motortransportkompanies.

Kleurlingkorps-motortransportkompanie, 136 en 137, het in die Nyldelta diens gedoen. Kompanie 138 en 139 het onderskeidelik in Gaza in Palestina en die Benghazi-area opgetree. Bo en behalwe die vervoertake, was hulle ook verantwoordelik vir die instandhouding van verbindingslinies in hulle onderskeie areas.

\section{Na die Tweede Wêreldoorlog}

Met die herorganisasie van die Unieverdedigingsmag na die oorlog is die Kleurlingkorps op 4 Julie 1947 as 'n eenheid van die Staande Mag ingelyf. Dit is egter in 1949 weer ontbind. Die Kleurlingkorps Hulpdiens is kragtens Wet 43 van 1949 gestig in 1950.

Op 1 April 1963 is die stigting van 'n Staandemagkorps vir Kleurlinge met ingang van 3 September 1963 gemagtig. Die eenheid is te Eerste- rivier opgerig en het as die Suid-Afrikaanse Kleurlingkorps bekend gestaan. In 1972 is die tradisionele naam na die Kaapse Korps verander. In dieselfde jaar is magtiging gegee dat Kleurlinge een jaar vrywillige diens in die SuidAfrikaanse Weermag kon verrig.

Die eerste inname het in 1973 met opleiding begin en in dieselfde jaar het lede begin met hulle offisiersopleidingskursus. Teen 1975 was daar heelparty junior offisiere in die Korps en huidig is daar reeds ' $n$ aantal senior en junior offisiere. In 1976 het die eerste lede van die Korps die Republiek vir operasionelediens verlaat.

Die gevolg hiervan was dat lede van die Kaapse Korps nou op ' $n$ gereelde basis in die operasionele gebied aangewend word. In 1980 is die vrywillige dienstydperk na twee jaar verleng. In hierdie jaar het die Korps ook in drie eenhede verdeel, nl die Kaapse Korpsskool, 1 SA Kaapse Korps Bataljon en die SA Kaapse Korps Onderhoudseenheid. Eers- en laasgenoemde word saam in een basis gehuisves.

Die Staandemaglede van die Kaapse Korps is ook in 1980 by hierdie funksionele groepe ingetrek. Diegene wat aansoek doen word eers aan 'n keuringsproses onderwerp, wat oa behels dat hulle deur ' $n$ span welsynoffisiere uitgevra word. Applikante moet ongetroud en tussen 17 en 28 jaar oud wees. Daarna moet hulle medies geskik bevind word. Indien ' $n$ applikant nie voldoen aan een van die vereistes nie, word hy weggewys.

Die KK Skool is verantwoordelik vir die uitplasing van offisiere na die Onderhoudseenhede asook die Bataljon. Elke eenheid in die Kaapse Korps het sy eie funksie en om aan hierdie funksie te voldoen, lei elke eenheid sy eie lede op. Die 1 SAKK Bataljon het ' $n$ twee weeklikse oriëntasieperiode waartydens vrywilligers die kans kry om te besluit of hulle die regte keuse gedoen het. ' $n$ Lid kan daarna onttrek as hy so sou besluit. Hierdie reëling dien ook as ' $n$ waardebepaling vir die Bataljon. Sodra ' $n$ persoon besluit om aan te sluit teken hy 'n twee-jaar-dienskontrak as vrywillige dienspligtige.

Hierna begin hulle basiese opleiding wat die eerste fase van die infanterie-opleiding is wat hulle as skutters moet voltooi. Na vyf weke keur die Bataljon sy gekwalifiseerde personeel en matrikulante wat hy mag benodig en hulle word dan na die KK Skool gestuur vir offisiersopleiding. Die Juniorleiers voltooi hulle basies en die 
gevorderde fase van Infanterie Offisiersopleiding by die Skool. Die operasionele kompanies word deur die Bataljon opgelei. Die SAKK Onderhoudseenheid het sy eie opleidingsprogram wat bestaan uit basies en dan ' $n$ spasiale fase in die spesifieke logistieke of ondersteuningsfunksies waarin die lid sal dien.

Die lede van hierdie drie eenhede dien die Weermag op dieselfde wyse as enige ander lid. Hulle doen ook grensdiens en ondergaan dieselfde kwalifiserende kursusse vir bevordering. Die rol wat die Kaapse Korps in die verdediging van Suid-Afrika speel, word goed besef. Waardering word getoon in die toekenning van die vryheid van sekere stede. So het die SAKK Onderhoudseenheid die Vryheid van Kuilsrivier ontvang en terwyl 1 SAKK Bataljon die Vryheid van Kaapstad en Belville ontvang het.

Die opleiding wat die lede van 1 SAKK Bataljon ontvang, is van 'n hoë standaard. Na hulle tweede fase van individuele opleiding en derde fase van teeninsurgensie-opleiding, gaan die Bataljon na die operasionele gebied. Hulle word vergesel deur ' $n$ ondersteuningskompanie wat bestaan uit ' $n$ mortierpeleton, ' $n$ storm-pionierpeleton, drywers en kokke. Hierdie lede word almal deur die Korps opgelei. Die Bataljon werk ook met die SA Mediese Skool (SAMS) saam waar die lede 'n stywe kursus in makkerhulp en 'n hospitaalfase ondergaan. Hulle word ook opgelei as drywers en moet die teeninsurgensiekursus voltooi.

Die derde eenheid van die Kaapse Korps is die SAKK Onderhoudseenheid. Sedert 1980 het hulle 2000 lede opgelei en 1061 van hulle het reeds grensdiens verrig. By hierdie eenheid word lede opgelei as stoormanne, klerke, drywers en kokke. Hulle lei ook hulle eie Regimentspolisie op. Die Kaapse Korps beskik oor al die fasiliteite om hom selfondersteunend te maak. In die Korps maak hulle ook voorsiening vir al die verskillende gelowe van die lede en godsdiens word vryelik beoefen.

Afgesien van die Suid-Afrikaanse Kleurlingkorps, word Kleurlinge ook aangetref in die SuidAfrikaanse Lugmag, die Vloot, die Suid-Afrikaanse Geneeskundige Diens en die kommando's. Die Vloot het reeds in 1963 met die werwing van Gekleurdes begin en hulle word sedertdien aangewend as stoormanne, seesoldate, kelners, militêre polisie en kokke. Kleurlinge in die Suid-Afrikaanse geneeskundigediens verrig klerklike- en logistiekedienste, terwyl die Lugmag wat in 1977 sy eerste Kleur-

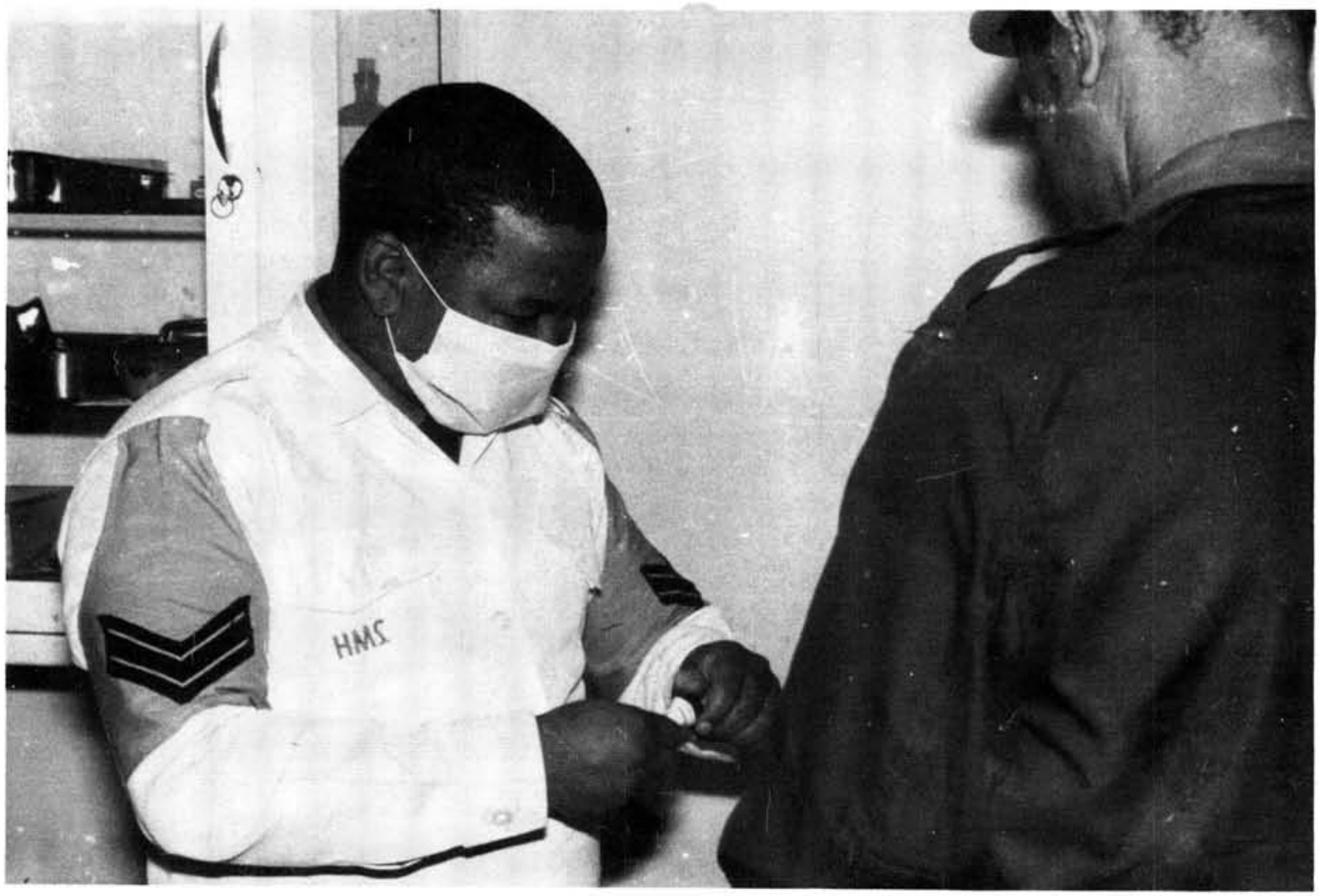

Mediese hulp word deur 'n lid van die Kaapse Korps verleen 


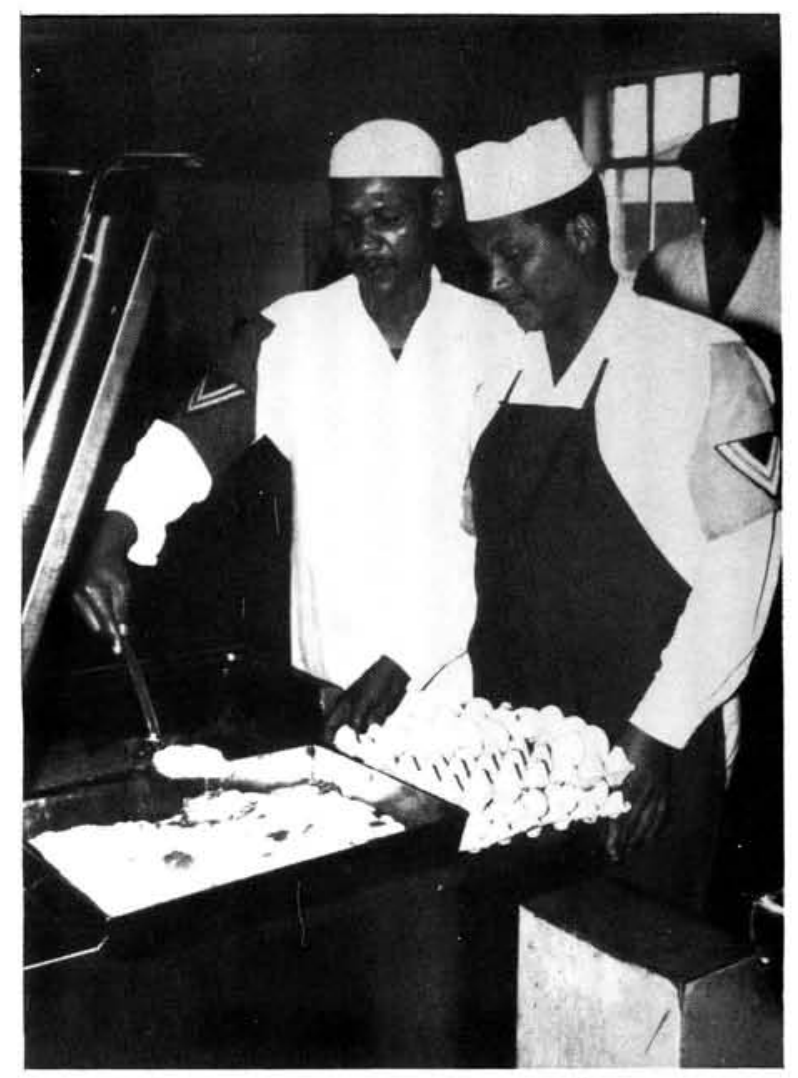

Kokke van die Kaapse Korps besig met voedselvoorbereiding linge aangestel het hulle as grondpersoneel opgelei het.

Hulle gesindheid spreek ook duidelik uit die leuse van die Suid-Afrikaanse Kaapse Korps Oudgediende Legioen nl: "Nie vir onsself nie, maar vir ander".

- KO A.M. Ie Roux, Hons Joernalistiek en Skakelkunde, verbonde aan MIB.

\section{Bronnelys}

1. Jacobs, F.J. (maj) en Ploeger, J. (dr), Kleurlinge in Militêre Verband, Militaria 4/2. Pretoria, 1974, o 39

2. John, P.N.. The Cape Corps: Proud Defenders of the RSA, Paratus Vol 36, No 5, Pretoria, Junie 1984, p. 6.

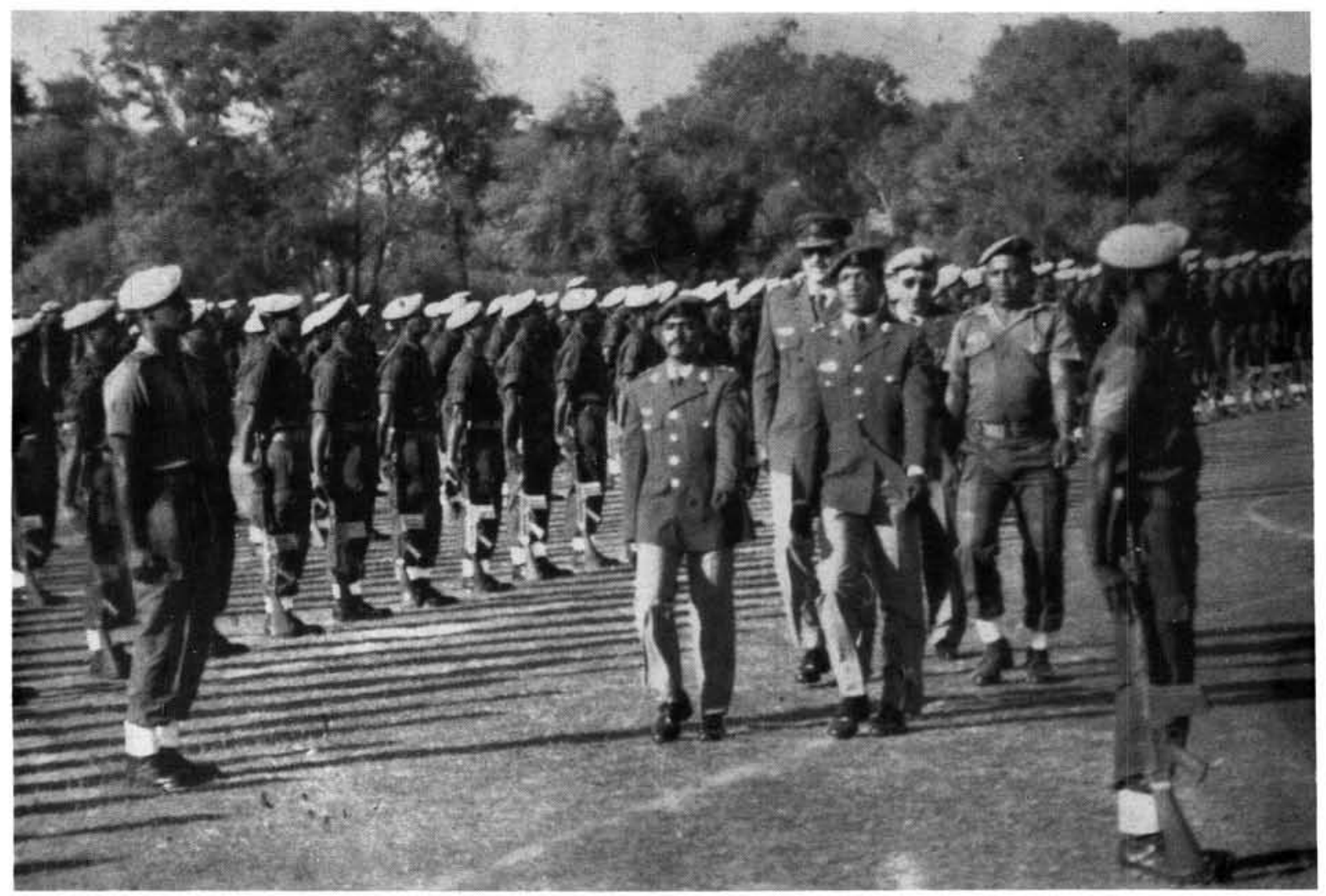

Lede van die Kaapse Korps op parade 